\title{
Challenges in Applying Artificial Intelligence for Supply Chain Risk Management
}

Submitted 25/06/20, $1^{\text {st }}$ revision 13/07/20, $2^{\text {nd }}$ revision $18 / 08 / 20$, accepted $25 / 09 / 20$

\section{Gerda Žigiené ${ }^{1}$, Egidijus Rybakovas²， Rimgailè Vaitkiené $\dot{3}^{3}$}

\begin{abstract}
:
Purpose: To define the scope and nature of challenges in applying artificial intelligence (AI) for supply chain risk management (SCRM).

Design/Methodology/Approach: Initial theoretical conceptualisation and respective approach were set by following the risk management maturity framework. The scope of explored challenges was defined by two data categories (supply chain risk events' and risk events' indicators) that are essential for AI tools to predict risk events' probability based on a set of risk prediction indicators. The nature of challenges is associated with the ways and forms of data collection, management, and application. The qualitative primary data research strategy was employed to explore selected case company practices associated with conceptually defined categories of scope and nature of challenges in applying AI for SCRM.

Findings: The article concludes with a conceptual typology of challenges in applying AI for SCRM defined by their scope and nature along with the selected illustrative practices.

Practical Implications: Empirical case study data based illustrative practices serve as research indicators or practical checklist entries for empirical evaluation of the level in progress towards the application of AI in SCRM. They also could be used as guidelines setting a direction for needed improvements in the way of applying AI for SCRM.

Originality/Value: This research contributes to the SCRM literature by defining the typology of challenges according to their scope and nature in applying AI for SCRM in the context of risk management maturity.
\end{abstract}

Keywords: Artificial intelligence, supply chain risk, risk management maturity.

JEL codes: G32, D81.

Paper Type: Research article.

\footnotetext{
${ }^{l}$ Faculty of Economics and Business, Kaunas University of Technology; gerda.zigiene@ktu.lt;

${ }^{2}$ Faculty of Economics and Business, Kaunas University of Technology; egidijus.rybakovas@ktu.lt;

${ }^{3}$ Faculty of Economics and Business, Kaunas University of Technology; rimgaile.vaitkiene@ktu.lt;
} 


\section{Introduction}

Enterprise risk management has been a recurring theme on the business organization agenda for many years. A successful risk assessment depends on many different factors. These include clearly defined scope, valid documentation, impartiality, the maturity of the risk analysis process, methods and organization of information collection and data security, the competence of the staff involved in the risk analysis, experience, and their role in the organization (Abkowitz and Camp, 2017). It is also necessary to assess the maturity of the organization itself in terms of risk identification and management before starting the risk analysis.

One particular area of risk management refers to an organization's supply chain risk management (SCRM) as the competition is increasingly established among the supply chains of organizations (Oliva, 2016). As stated by Oliva (2016), "The enterprise risk analysis should consider a scope beyond the boundaries of the organization, that is, the enterprise risk analysis of the organization should include the enterprise risk analysis of its supply chain" (Oliva, 2016).

The purpose of this article is to define the scope and nature of challenges in applying artificial intelligence for supply chain risk management. It is supposed that the implementation of artificial intelligence might help to fix most of the current imperfections in SCRM. This article further explores what potential attributes are required to implement $\mathrm{AI}$ to business practices for managing risk in a supply chain. SCR decomposition in terms of risk events and risk indicators contributes SCRM field with the idea to define the challenges of incorporating AI in SCRM. Since technically and methodically AI is already specified, it is expected that these challenges and guidelines of how a better SCRM supplemented by AI techniques will serve as missing link integrating SCRM and AI research fields.

One of the potential prerequisites of incorporating AI in SCRM is the need for particular data. Companies usually collect different sets of data, struggling to use it constructively. Although when it comes to the analysis of the collected data here the human hypotheses steps into the play, as a value was largely driven by goals of internal decision support rather than advanced predictive capabilities or cognitive insights. The decision-maker may construct his or her decision-making behaviour to constrain the opportunity for new information to alter the initial perception and choices made (Raisinghani, 2004). Even the same set of data or ratios might be interpreted differently by different employees at the same company and it affects the decision-making process as well as implies the space for intuitive conclusions and therefore human mistakes. As appeared in our interviews, even large commercial enterprises struggle to manage risk occurring in the supply chain process as managers faces challenges in understanding the impact of different internal and external factors on the risk. They strive to judge and interpret the available evidence on the possibility of loss and how to take individual actions to manage the risk (Tse et al., 2018; 2019). Not only numerous risk management definitions, models, 
techniques, and tools make the complexity in the individual decision but also different information streams and business intelligence tools.

In this paper two data categories - SC risk events registry and their prediction indicators - are considered as two distinct fields in the scope of challenges in applying AI for SCRM.

The paper is organised in the following way. The theoretical framework delineates a research territory: risk of a supply chain is perceived from the approach of the maturity level of enterprise risk management and potential implementation of AI in SCRM. A supply chain risk and company's maturity in assessing and controlling it appropriately is discussed as one of the important factors affecting the ability to foster supply chain risk management by moving towards more mature risk identification and control as well as incorporate such tools as artificial intelligence for risk management efficiency. The methodology part explains the selection of case analysis in a complex holding company, conducting 7 interviews with the representatives of different subdivisions in order to assess the approach $f$ a focal company to a supply chain risk and its management. Management practices of various kinds in supply chain risk events' and risk indicators' data collection, storing, management, exchange, and application are discussed in a result part of the paper, followed by conclusions.

\section{Theoretical Framework}

Maturity of risk analysis in a context of supply chain risk management:

Risk is one of the negative factors that decrease and destroy the competitiveness of any business (Žigienè et al., 2019). ISO Guide 73 defines a risk assessment as the overall process of risk identification, risk analysis, and risk evaluation (ISO, 2009).

Assessing the level of maturity of an ERM is very important as it allows identification of strengths and weaknesses from which the organization can obtain the means for filling existing shortcomings and improve corporate governance and risk management. Only by determining the level of maturity, appropriate risk analysis and management methods can be identified (Farrell and Gallagher, 2015; ISACA, 2019; Oliva, 2016).

Table 1. Supply chain risk management maturity levels based on the general approach of enterprises risk management

\begin{tabular}{|l|l|}
\hline Not present & $\begin{array}{l}\text { The organization does not recognize or does not meet SC risks. SC risk management } \\
\text { procedures are not defined. }\end{array}$ \\
\hline Initial/Ad & $\begin{array}{l}\text { There is general recognition of SC risks in the organization. Standardized processes } \\
\text { are not developed. Risk management procedures and respective decisions are made } \\
\text { on the ad-hoc bases, at the individual level. Management typically depends on the } \\
\text { actions of specific individuals, with improvised procedures and poorly understood } \\
\text { processes. Risks are managed case by case. The response from managers and } \\
\text { functional executive officers is based on personal experience, analytical and data }\end{array}$ \\
\hline
\end{tabular}




\begin{tabular}{|l|l|}
\hline & $\begin{array}{l}\text { management tools are developed on the backgrounds of personal experience, skills, } \\
\text { and capabilities. }\end{array}$ \\
\hline $\begin{array}{l}\text { Iterative/ In } \\
\text { Silos }\end{array}$ & $\begin{array}{l}\text { Different people performing similar functions apply similar procedures, which are } \\
\text { not unified and still performed on the personal or separate department bases. Risk is } \\
\text { managed in silos, with little integration or risk aggregation. The responsibility } \\
\text { remains personal. SC risk management relevant data is collected and systematized by } \\
\text { individuals, which results in data and process duplications. Procedures are not } \\
\text { defined, but they are performed. }\end{array}$ \\
\hline $\begin{array}{l}\text { Defined/Re } \\
\text { peatable }\end{array}$ & $\begin{array}{l}\text { SC risk management procedures are defined and standardized. These procedures } \\
\text { include SC risk-relevant data collection, management, and standardization. Though } \\
\text { procedures are defined, they are not obligatory. People use them occasionally, which } \\
\text { results in collected data fragmentation, shortages in analytical processes. Approaches } \\
\text { to risk management are established and repeatable }\end{array}$ \\
\hline Manageable & $\begin{array}{l}\text { SC risk management activities, such as monitoring, measurement, and reporting are } \\
\text { integrated and harmonized with measures and controls established. However, data } \\
\text { management automatisation, systematization, and technical analytical tools are used } \\
\text { only occasionally. Most of analytical procedures are made manually. The general } \\
\text { understanding of SC risk management is common across organization and different } \\
\text { management levels, but analytical processes could be interrupted due to } \\
\text { shortcomings of systematized data about potential risk events and indicators for } \\
\text { estimation of events' probability. }\end{array}$ \\
\hline Optimized & $\begin{array}{l}\text { Risk-based discussions are embedded to a strategic level, such as longterm planning, } \\
\text { capital allocation, and decision making. SC risk estimation and management are } \\
\text { performed by technical tools, which automatically collect needed data, calculate risk } \\
\text { events' probabilities, and deliver respective management decisions suggestions. SC } \\
\text { risk management is integrated into all other business processes. Connections with } \\
\text { internal and external data sources are established and properly working. }\end{array}$ \\
\hline
\end{tabular}

Source: Adapted from Farrell and Gallagher (2015), ISACA (2019), Lindberg and Seifert (2011).

Enterprise supply chain risk analysis, as an important part of the overall enterprise risk management, plays an important role. Supply chain risk analysis seeks to identify the key risks that affect business processes and relationships: relationships with suppliers, relationships with customers, managing relationships with customers (Bavarsad et al., 2014; Chen, 2018; Chen and Liao, 2018; Colicchia and Strozzi, 2012; Fan and Stevenson, 2018; Fraser and Simkins, 2016; Noja, 2018). Organizations strive for continuous process evolution, which is also found in risk management. "The unpredictability of the business environment, variable consumer demands, actions by competitors, along with market dynamics and continuous improvement initiatives within organisations imply that the supply chain never actually reaches a stable steady-state" (Colicchia and Strozzi, 2012). The data and methods of analysis differ from company to company, from industry to industry, and every company has its own set of data, tools, and practices. However, some parts of commercial processes as SC management have some common elements.

SCRM is defined as referring to "the extent of information availability about randomly changing supply chain parameters" (Heckmann et al., 2015). The SC thus is seen as a set of interactions that start in supplier's premises and end when the buyer receives products and uses or consumes them. The focal company, which manages the SC process, i.e., makes orders, pays suppliers in advance for ordered 
goods, contracts carriers, ships the goods to buyers, delays payment requirements, receives payments from buyers, etc. is a subject at SCRs. Risk events cause losses of money or products which are suffered by the focal company. Not material losses of reputation also could be caused by risk events, but these negative SCR outcomes are relatively rare. SCRM respectively covers managerial decisions and actions aimed at mitigating risks and potential losses caused by risk events if they occur.

\section{Incorporating AI into supply chain risk management:}

Supply chain risk identification, assessment, and management require to consider a wide range of indicators defined both inside and outside the organization. Not only data abundance but also potential biases, personal attitudes, and judgments, implicitness, the limited scope of considered risks - are issues caused by conventional business analytics applied in supply chain risk assessment and management. Intensified use of innovative technologies, such as artificial intelligence for the company's risk management, is a way to achieve the company's goals faster and to run organizational processes more smoothly. It is supposed that the implementation of artificial intelligence would help to eliminate most of the current imperfections. This is why the conceptual basis is needed to facilitate artificial intelligence development.

The generalised definitions and processes of AI development were defined by Debrev (2012), Andriole (2019), Tecuci (2012), Akerker (2019a), and other authors. It was conceptualised that the development of AI tools or the process of embedding AI into the business process covers a set of steps starting with problem recognition, following with identifying data sources, and finally finding an appropriate AI solution (Akerkar, 2019a). The identification of data sources as the most challenging phase is explored in this research.

Dobrev (2012) made three conceptual assumptions regarding AI: first: AI is made of the set of programs, then: "AI is a step device and on every step, it inputs from outside a portion of information ... and outputs a portion of information", and third: "AI is in some environment which gives it a portion of the information on every step and which receives the output of AI". Transferred to the context of AI application for SCRM the AI environment providing it with the needed information and then receiving outputs is a business organization managing its supply chain processes. And this environment should be able to serve AI with needed information and then receive outputs. This research is focussed mainly on this point - challenges in business organization arising when it deals with the requirements to develop and maintain AI in SCRM providing it with appropriate data.

The level of progress towards the application of AI in SCRM in organizations could be estimated following the general risk management maturity framework. The core and very essence of AI in supply chain risk management is a prediction of potential risk events, that could cause business losses, i.e., AI in SCRM is expected to do some predictive analytics (Akerkar, 2019a, 2019b). The prediction as a mathematical 
construct is based on calculations that estimate the probability of events. Probability estimation is done on the backgrounds of the set of prediction variables. This simple logical chain suggests that core pillars in AI development are data on risk events (as the set of predicted variables) and data on risk factors (as the set of prediction indicators). In general, the AI works with data; the case of supply chain risk management also is the same.

Figure 1. Risk management maturity levels in association with the scope and nature of challenges in applying AI for SCRM

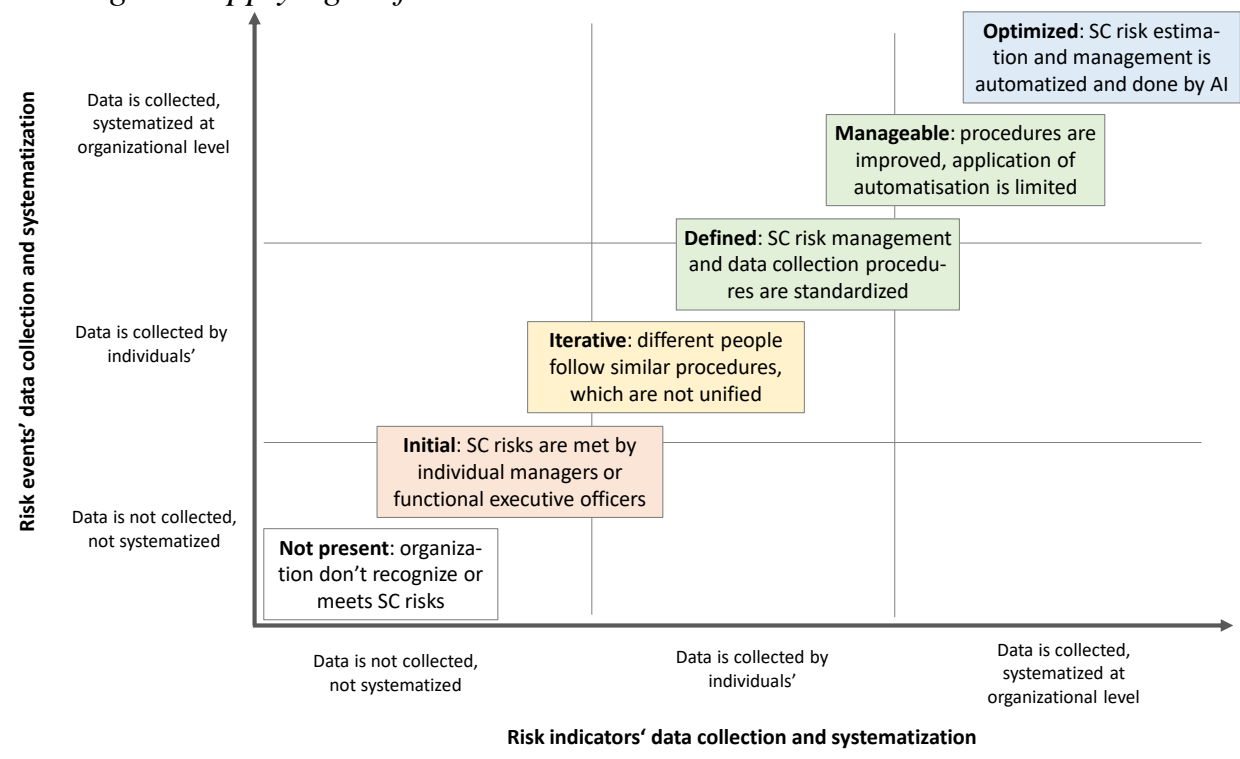

Source: Own study.

The data collection and systematization practices in organizations are not an unambiguous phenomenon. These practices could be realized both at individual and organizational levels. Collected data of the company's operations gives us the facts and information that allows us to conclude, various business intelligence tools provide the basis for making good business decisions (Raisinghani, 2004) in order to understand business opportunities, strengths, and weaknesses (Ain et al., 2019). The research data indicates that individually performed data collection and systematization are not suitable for AI tools development due to the implicitness and limited opportunities to integrated different data into a single framework of organization wide SC risk estimation and management (Aqlan and Lam, 2015; Davenport, 2018; Soni and Kodali, 2013).

Individual initiatives and practices mostly are based on individual experience and solutions, they lack systematization, integration, often are based on basic analytical and data management skills. The prevalence of individual experience-based practices of supply chain risk management relevant data collection and 
systematization is one more limitation and respective challenge in applying artificial intelligence for supply chain risk management.

As a principal theoretical-conceptual attitude taken by this research it is stated that the potential application of artificial intelligence tools requires for few supply chain risk management practice attributes. These attributes in current day business practices are seen as prerequisites for AI tools development. The attributes of supply chain management practices are defined as risk events' data collection and systematization and risk indicators ' data collection and systematization. If the data in these two categories is not collected, not systematized in organization's supply chain management practice, then the potential for AI development would be limited, restricted, and thus challenged. Data collection, storage, management, exchange, and application attributes of SCRM practices represent a scope of potential challenges for AI applications.

The improvements in either of these two dimensions would increase the potential to develop AI-based supply chain risk management, but challenges would be noticeable due to limitations in data on either predicted (outcome) variables either prediction indicators. Besides, this variation is considered as the nature of challenges. The most desirable situation from this perspective is a combination of both indicators' and outcome variables' data collection and systematization. It would correspond to an optimised state according to the generalised risk management maturity estimation framework. It is expected that organizations that meet these prerequisite conditions would reach high potential for developing AI tools for supply chain risk management.

\section{Research Methodology}

The theoretical considerations on SCRM and potential for application of AI in SCRM suggest that the scope of challenges in applying AI for SCRM extends along management practices appointed to data needed to predict risk events collection, storing, exchange, management, and application. Two data categories - i.e. SC risk events registry and their prediction indicators - are considered as two distinct fields in the scope of challenges in applying AI for SCRM. The nature of the considered challenges is captured by the categorization of managerial practices according to their maturity levels which are set by the concept of risk management maturity. On the background of such a theoretical framework, the empirical research was done to find illustrative practices (organizational features), that could be used in other research as indicators to estimate the level of progress towards the application of AI in SCRM.

The case study research method allows us to explore the phenomenon more precisely within its natural settings (Yin, 2009). Gomm et al. (2000) define that case studies are the strategies of inquiry, which explores a real-life, contemporary 
bounded system over time, through detailed, in-depth data collection involving different sources of information.

Case selection:

In selecting a case for the study, the aim was to identify an information-rich case, from which much can be learned about the phenomenon. Application of AI for SCRM is not an established concept and the levels and types of adoption in the company are currently unclear. Several criteria were imposed when selecting the target case to study. The firm (for confidentiality referred to as The Holding Company) has extensive experience in a range of different industries and markets. Second, the selected case company had to be performing its business in supply chains on width and depth bases. Third, selected the Holding Company initiated the implementation of AI for SCRM during the research period. We think that these criteria ensured that collected primary data is appropriate and sufficient to achieve the above-stated aim of empirical research.

The Holding Company is specialized in the supply and distribution of commodities and raw materials. It is one of the most diversified commodity and raw materials distribution groups in Eastern Europe. The activities are grouped into several business segments (biofuel, agricultural products, textile, processed food, energy, packaging, industry, services, and plastic materials). Today, The Holding Company has trade relations in 70 countries worldwide, with the main trade markets in Europe.

\section{Data collection:}

Data were collected from May to July 2019 through 7 semi-structured interviews, lasting 145 minutes on average. We discussed with senior executives about which employees would be most appropriate to provide in-depth insights relevant to the research question. Heads of Finance (A), Accounting (B), Logistics (C), Law (D), Prevention and vindication $(\mathrm{E})$, IT $(\mathrm{F})$, and SEO $(\mathrm{G})$ participated in the research. All informants were experienced and represented business support functions in the selected enterprise. They were able to critically examine the supply chain risk events and their indicators data collection and systematization practices in the large commercial company operating in a wide range of different industries.

All interviews were conducted by three researchers, recorded and transcribed verbatim within $17 \mathrm{~h}$. The 112 pages of transcriptions were officially approved by the Holding Company representatives to ensure the reliability of obtained information (Yin, 2009).

Data analysis:

MaxQDA 18 software was used for qualitative analysis of the interview transcripts. Each step of the analysis was conducted separately by the two researchers and thereafter jointly agreed. The transcribed interview data were coded by key researched categories (i.e., supply chain risk events' data collection and systematization practices; as well as a supply chain risk indicators ' data collection 
and systematization practices) defining the scope of challenges for the application of AI in SCRM. Coded data in each of these two main categories then were sub- coded into three subcategories defining the nature of challenges in applying AI for SCRM.

Analysis of explored challenges nature, i.e. coding of observed data collection, storing, management, and application practices with the categories defining the nature of the challenges, revealed one more data category - i.e. reasons and causes that prevent from advancement to the desired state appropriate for $\mathrm{AI}$ - when risk events' and risk indicators' data is collected, stored, managed, exchanged, and applied for risk assessment and management at the organizational level through organization-wide infrastructure.

Thereafter, a cross-analysis of coded practices was conducted by using data matrixes displaying each element with axial coding. The outcomes of the research, discussed in the following chapter, due to the exploratory character of qualitative research design (Siggelkow, 2007), should help to understand better what challenges defined by the theoretically preassigned scope and nature prevent companies from the successful application of AI for SCRM and how to identify and notice these challenges.

\section{Results}

The qualitative data analysis was done to explore SCRM practice in the business organization that is in the transition to the organization-wide application of AI in SCRM. This context was found as appropriate for the empirical reveal of challenges in applying AI for SCRM of variating nature. Tables 2 and 3 provide primary research data quotes that were coded as management practices of various kinds in supply chain risk events' and risk indicators' data collection, storing, management, exchange, and application.

The variation in nature of challenges in applying AI for SCRM is spanned by three kinds of observed managerial practices categorization: including the first level that is categorized and defined as "Data is not collected, not systematized", which corresponds to two initial levels of risk management maturity; the second group of practices is categorized as "Data is collected and systematized by individual initiative-based practice", which represents intermediate levels of risk management maturity; and finally research category "Data is collected and systematized by organization-wide systemic practices" is intended to represent the mature state of risk management.

These quotes from primary data then were redefined to provide a set of illustrative organizational features that could be used as checklist entries to estimate the level of progress towards the application of AI in SCRM. These research outcomes are considered in the discussion and implications chapter. 
Table 2. Selected quotes from interviews depicting supply chain risk events' data collection and systematization practices as prerequisites for AI tools development

\begin{tabular}{|c|c|c|c|}
\hline \multirow{2}{*}{$\begin{array}{l}\text { Research } \\
\text { categories }\end{array}$} & \multirow{2}{*}{$\begin{array}{l}\text { Data is not collected, not } \\
\text { systematized }\end{array}$} & \multicolumn{2}{|c|}{ Data is collected, systematized } \\
\hline & & $\begin{array}{l}\text { Individual initiative- } \\
\text { based practice }\end{array}$ & $\begin{array}{l}\text { Organization wide } \\
\text { systemic practices }\end{array}$ \\
\hline $\begin{array}{l}\text { Risk events' } \\
\text { data collection } \\
\text { and } \\
\text { systematization }\end{array}$ & $\begin{array}{l}\text { "when a contract is executed, you } \\
\text { have to ensure, that all entries are } \\
\text { safely kept, we did not have them } \\
\text { all secured" (B), } \\
\text { "it happens that clients purchase } \\
\text { data do not match with ours' sales } \\
\text { data, [...] then it is difficult to } \\
\text { trace where was the mistake" (E), } \\
\text { "when data about events is not } \\
\text { collected, no one takes care, no } \\
\text { decision are being made" (G), } \\
\text { "no, we do not have such mark in } \\
\text { our system to indicate the event } \\
\text { that caused some troubles" (A). } \\
\text { "we do not have such a tool that } \\
\text { would chronologically show all } \\
\text { that had happened in the business } \\
\text { operations" (A), } \\
\text { "theft from the warehouse is } \\
\text { possible, [...] and could identify } \\
\text { it, when you hear that someone is } \\
\text { selling your products much } \\
\text { cheaper" (E), } \\
\text { "it would be nice to have the } \\
\text { system, that could check automa- } \\
\text { tically and notify when payments } \\
\text { are delayed for } 30 \text {, } 60 \text { days, in } \\
\text { case delay exceeds } 90 \text { days low } \\
\text { department should be engaged" } \\
\text { (D), } \\
\text { "sales should be stopped auto- } \\
\text { matically if the debt period exce- } \\
\text { eds some predefined time, e.g. } 60 \\
\text { or } 90 \text { days" (D), } \\
\text { "it is not systematized no how; if } \\
\text { that happens, you simply make a } \\
\text { decision do not sell for this } \\
\text { client" (E), }\end{array}$ & $\begin{array}{l}\text { "when contracts' details } \\
\text { are needed to check after } \\
\text { some time, managers not } \\
\text { always can provide all of } \\
\text { the details" (B), } \\
\text { "we are ticking by hand } \\
\text { when order is completed } \\
\text { successfully, actually } \\
\text { number of negative events } \\
\text { is very small and it is not } \\
\text { relevant to develop some } \\
\text { system for this reason" } \\
\text { (C), "it was that one of our } \\
\text { managers during his } \\
\text { holidays arranged with } \\
\text { client that payment will be } \\
\text { made, but this was not } \\
\text { confirmed in the system, } \\
\text { and products were shipped } \\
\text { for another customer" (E), } \\
\text { "managers and officers, } \\
\text { they get e-mails with } \\
\text { urgent requests to transfer } \\
\text { money to clients, [...] they } \\
\text { have to take care about } \\
\text { these requests, the } \\
\text { communication channels } \\
\text { do not prevent from } \\
\text { spurious contacts" (E), } \\
\text { "we have to filler } \\
\text { payments data to review } \\
\text { the information that is } \\
\text { needed" (A), "we have lists of debtors, } \\
\text { "we, we make them [lists] } \\
\text { sure, oursonally, on our own" } \\
\text { (A), }\end{array}$ & $\begin{array}{l}\text { "we have all } \\
\text { payments history } \\
\text { stored in our system; } \\
\text { at any time we can } \\
\text { check if the } \\
\text { payments are } \\
\text { delayed, what is } \\
\text { agreed payments } \\
\text { period" (A), } \\
\text { "our system can } \\
\text { check all contracts, it } \\
\text { sends automatic } \\
\text { notifications when } \\
\text { payments are } \\
\text { delayed" (B), } \\
\text { "if the transportation } \\
\text { order is associated } \\
\text { with the actual } \\
\text { purchase, then the } \\
\text { system can prove } \\
\text { that order, orders are } \\
\text { crosschecked" (C), }\end{array}$ \\
\hline
\end{tabular}

Source: Own study.

All three data collection, storing, management, exchange, and application practice categories defining the variating nature of challenges in applying AI for SCRM were observed in the selected case company. Clients' payments history tracking, delayed payment notifications, and transportation orders crosschecking are instances that reveal existing risk events' occurrence data collection practice. The quotations lists' of instances of risk events' indicators data collection and management on individual experience and individual responsibility based and pieces of evidence of no data 
collection are much more extensive and comprehensive (Table 3). This is reasoned and explained by the fact that the researched organization currently founds itself in the transition towards the extensive application of AI for SCRM.

Not only those practices that were categorized as representing a mature state of risk management will be taken as empirical backgrounds to define illustrative organizational features that could be used to estimate the level of progress towards the application of AI in SCRM. Quotations representing not mature risk management categories also were treated as relevant organizational features; they were defined in the opposite ways to represent them as required practices.

The number of instances and respective quotations revealing supply chain risk indicators' data collection, storing, management, exchange, and application practices are larger. The indicators describing clients and suppliers, carriers, orders, appropriate contract documentation are collected, stored, managed, and applied for supply chain risk assessment through organization-wide infrastructure. But the mature state of risk management is not yet reached and this is seen by quotations which indicate that a wide range of relevant data still is not collected, or their collection and storage is delegated to the individual managers, which is not an appropriate direction in the context of attempts to apply AI for SCRM.

Table 3. Selected quotes from interviews depicting supply chain risk indicators ' data collection and systematization practices as prerequisites for AI tools development

\begin{tabular}{|c|c|c|c|}
\hline \multirow{2}{*}{$\begin{array}{l}\text { Research } \\
\text { categories }\end{array}$} & \multirow{2}{*}{$\begin{array}{l}\text { Data is not collected, not } \\
\text { systematized }\end{array}$} & \multicolumn{2}{|l|}{ Data is collected, systematized } \\
\hline & & $\begin{array}{l}\text { Individual } \\
\text { practice }\end{array}$ & $\begin{array}{l}\text { Organization wide } \\
\text { systemic practices }\end{array}$ \\
\hline $\begin{array}{l}\text { Risk indicators } \\
\text { data collection } \\
\text { and } \\
\text { systematization }\end{array}$ & $\begin{array}{l}\text { "data is not systemic, they } \\
\text { are more like single } \\
\text { messages" (A), } \\
\text { "we get data and we save } \\
\text { it on our own, we do not } \\
\text { put them into some } \\
\text { system or somewhere" } \\
\text { (A), } \\
\text { "often data is in scanned } \\
\text { format, not in excel files" } \\
\text { (A), "when earlier contracts } \\
\text { data is needed and } \\
\text { management staff was } \\
\text { changed we could not } \\
\text { restore previous e-mails" } \\
\text { (B), "some indicator should be }\end{array}$ & 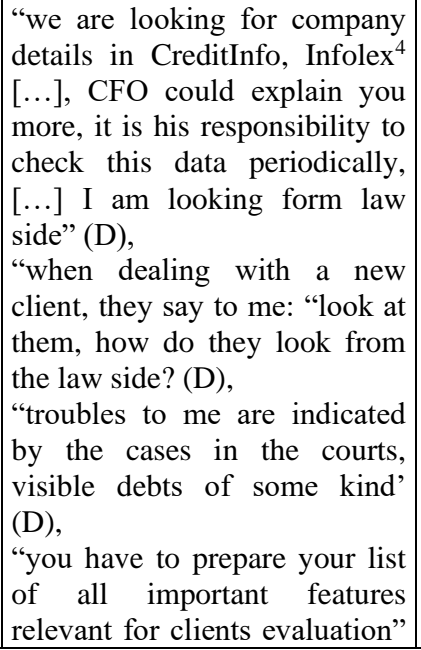 & $\begin{array}{l}\text { "we have clients' } \\
\text { insurance information } \\
\text { on an extended form } \\
\text { of client's card, it } \\
\text { indicated where } \\
\text { insurance was issued, } \\
\text { we see these essential } \\
\text { things" (G), } \\
\text { "the data about } \\
\text { changes in orders } \\
\text { processing is stored in } \\
\text { our system, but it is } \\
\text { difficult to have all } \\
\text { relevant data in } \\
\text { chronological } \\
\text { sequence" (C), } \\
\text { "we can set the filters, } \\
\text { to review contracts by }\end{array}$ \\
\hline
\end{tabular}

${ }^{4}$ „CreditInfo“ and ,Infoles“ are local business and national courts data providers. 


\begin{tabular}{|c|c|c|c|}
\hline \multirow{2}{*}{$\begin{array}{l}\text { Research } \\
\text { categories }\end{array}$} & \multirow[b]{2}{*}{$\begin{array}{l}\text { Data is not collected, not } \\
\text { systematized }\end{array}$} & \multicolumn{2}{|l|}{ Data is collected, systematized } \\
\hline & & $\begin{array}{l}\text { Individual initiative-based } \\
\text { practice }\end{array}$ & $\begin{array}{l}\text { Organization wide } \\
\text { systemic practices }\end{array}$ \\
\hline & 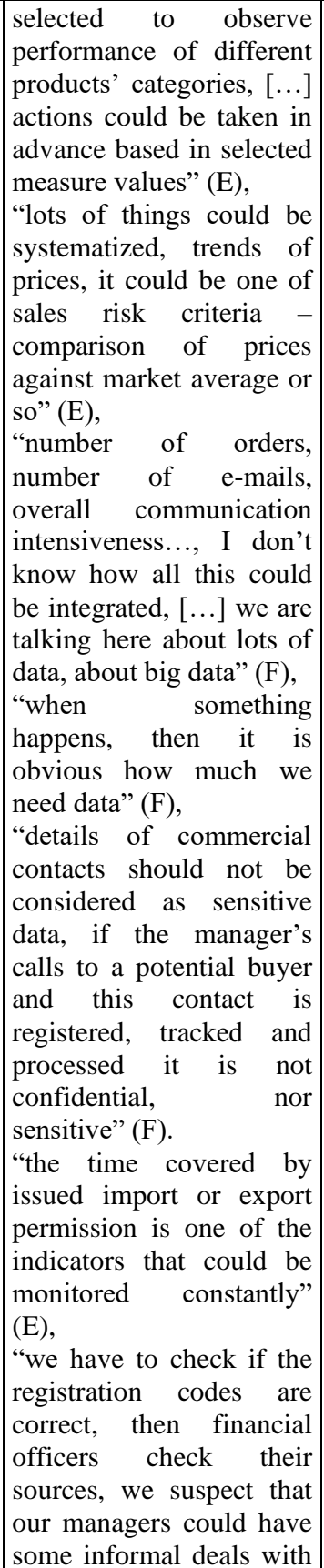 & $\begin{array}{l}\text { (D), } \\
\text { "debt for Sodra is hanging for } \\
\text { some months, another debt for } \\
\text { VMI, [...] are clients' troubles } \\
\text { indications also to me" (D), } \\
\text { "rumors in the market, [...] } \\
\text { most in business know each } \\
\text { other and there are lots of } \\
\text { informal information around" } \\
\text { (E), } \\
\text { "there are indications, changes } \\
\text { in shareholder structure could } \\
\text { indicate something" (E), } \\
\text { "you could visit the client and } \\
\text { ask for some data to estimate } \\
\text { its risk" (E), } \\
\text { "when you know who is } \\
\text { working with whom, then you } \\
\text { could ask the manager directly } \\
\text { about the client, [...] to check } \\
\text { its internal sources in clients" } \\
\text { organizations" (E), } \\
\text { "when prices are changing } \\
\text { significantly, then you have to } \\
\text { go deeper, to investigate the } \\
\text { situations and realize what's } \\
\text { happening" (E), } \\
\text { "we estimate local market data, } \\
\text { we review them from time to } \\
\text { time" (A), } \\
\text { "first manager decides on how } \\
\text { much he needs to insure } \\
\text { purchase, and then we look at } \\
\text { our data, what we have" (A), } \\
\text { "we estimate the number of } \\
\text { employees, date of company } \\
\text { establishment, payments of } \\
\text { taxes, financial statements and } \\
\text { other data, that seems currently } \\
\text { relevant" (A), } \\
\text { "you have to estimate and } \\
\text { decide whether the event is } \\
\text { significant and credit limit has } \\
\text { to be abandoned" (A), } \\
\text { "it is seen simply in the pay- } \\
\text { ments history, you could } \\
\text { observe, when payments start } \\
\text { to be delayed" (A), }\end{array}$ & $\begin{array}{l}\text { date, by contract type } \\
\text { and more other } \\
\text { characteristics" (B)", } \\
\text { "the product manager } \\
\text { has to enter } \\
\text { information into the } \\
\text { system, indicating } \\
\text { where the products } \\
\text { are, when they have to } \\
\text { be picked up, who will } \\
\text { pick them up; then } \\
\text { this information is } \\
\text { sent to the department } \\
\text { that manages relations } \\
\text { with clients; [...] there } \\
\text { all this information is } \\
\text { finally processed" (C), } \\
\text { "we [transportation } \\
\text { department] also have } \\
\text { carriers profiles as } \\
\text { sales department has } \\
\text { clients profiles; we } \\
\text { store there data on the } \\
\text { number of the trucks, } \\
\text { insurance, how old the } \\
\text { company is, any } \\
\text { recommendations in } \\
\text { case we have them" } \\
\text { (C), } \\
\text { "we have clients' or } \\
\text { suppliers' profiles, } \\
\text { often we do not } \\
\text { distinguish between } \\
\text { clients and suppliers, } \\
\text { we treat them as } \\
\text { partners, who could } \\
\text { become either client } \\
\text { or supplier" (G), } \\
\text { "standardized } \\
\text { schemes define, what } \\
\text { documents and when } \\
\text { should be collected } \\
\text { and checked [though } \\
\text { these procedures are } \\
\text { not automated]" (B), }\end{array}$ \\
\hline
\end{tabular}

${ }^{5}$,Sodra" is a local governmental social insurance service provider in Lithuania that administrates social insurance taxes paid by businesses. 


\begin{tabular}{|c|c|c|c|}
\hline \multirow{2}{*}{$\begin{array}{l}\text { Research } \\
\text { categories }\end{array}$} & \multirow{2}{*}{$\begin{array}{l}\text { Data is not collected, not } \\
\text { systematized }\end{array}$} & \multicolumn{2}{|l|}{ Data is collected, systematized } \\
\hline & & $\begin{array}{l}\text { Individual initiative-based } \\
\text { practice }\end{array}$ & $\begin{array}{l}\text { Organization wide } \\
\text { systemic practices }\end{array}$ \\
\hline & $\begin{array}{l}\text { clients, so we have to } \\
\text { check all new clients (G), } \\
\text { "it is difficult to check all } \\
\text { clients' data in the cases } \\
\text { of international contracts; } \\
\text { we check VAT payer's } \\
\text { code, and that is all, data } \\
\text { availability is limited" } \\
\text { (B), }\end{array}$ & $\begin{array}{l}\text { "if the client wants to pay cash } \\
\text { you guess that maybe its } \\
\text { accounts are suspended" (A), } \\
\text { "our accountants, they have to } \\
\text { check all contracts, to ensure } \\
\text { that all documents are signed, } \\
\text { all needed formalities are } \\
\text { fulfilled" (B), } \\
\text { "we have detailed descriptions } \\
\text { of typical procedures, when } \\
0 \% \text { VAT rate could be } \\
\text { applied" (B), }\end{array}$ & \\
\hline
\end{tabular}

Source: Own study.

Challenges in applying AI for SCRM are associated with the coded practices. As it already was explained, challenges are concentrated at the intersections of different scopes and kinds of nature. Most extensive challenges are expected when an organization does not collect, stores, manages, applies neither risks' events', nor risks' indicators' data. As it is suggested by the risk management maturity framework, these challenges will diminish by changing supply chain risk events' and their indicators' data collection, storage, management, exchange, and application practice from those based on individual experience and responsibility to ones embedded as organization-wide infrastructure.

Besides the above-considered practices that reveal the scope and nature of challenges in applying AI for SCRM, the primary data also were explored for the reasons and other organizational circumstances that prevent the organization from progress towards the application of AI for SCRM. The following categories were considered and data coded as exposing general reasons limiting AI development:

- Employees and officers see no point: “... I don't collect, I don’t have it” (A);

- Experiencing new situations, experiences: "when you're making a deal somewhere... need to have that place to keep a record. We, of course, didn't have that..." (B);

- Couldn't get the required data: "You can just go there, have a talk and that's that. Now who's going to open up their kitchen for you? It doesn't work that way. No such documents exist." (E);

- A need for such data arises unexpectedly: "I can identify this when some kind of event happens, that's when you really need the data" $(F)$,

- Sometimes employees don't even know what kind of data is collected and which departments handle this. “...I don't think they are collected in some special way..." (D). 
It was also observed, that situations arise in The Holding Company when data is being collected, but not organized or analyzed. The main reasons for this are:

- Incompatibility of data formats: “...this data is usually scanned, not Excel...” (A),

- Data is fragmented: "No no, in organizing it's difficult to get,... these are more of isolated messages..." (A),

- Difficult to process: “... we are archiving them somehow, but we're not entering them to the system, to have something run automatically" (A),

- Not seeing the point of data analysis: "... so again, maybe it could also be possible to store those scanned documents in some kind of data storage... because if somebody will check them, there is no telling when, but they will definitely be checked" (B),

- Lack of needed competence: “...there are many such things... how to organize them?"(E),

- The amount of data is too large: ".. so, the amount of data is very large... as I've said, it's like that here... (F).

The individual experience-based practice is often encouraged by a general approach taken in the Company's supply chain risk management. The establishment of these practices is often motivated by the following reasons:

- Aim to reduce risk in the single supervised area of work (expert's area of responsibility): "...when having the sum of these indications the restructuration has started. And bankruptcy procedure also. The beginning is enough, don't even need the ending. When it begins it means that either way you already have a problem" (D),

- Elimination of human error: "Need to check it, because it's not necessarily malicious - might be due to haste. Due to haste, because especially with large volumes, when you read the same thing for the hundred twentieth time..." (B),

- Implementing new practices: “...it's still possible to keep everything in check, those emails, that what the row shows, for example, title with real IP addresses to check whether it matches" (A),

- Intuitive needs to adapt new practices: "yes, at that point you pretty much know who's working with that client, then you try to delve into the details. Look, they wrote this and that, please ask your source from the inside if it's possible to somehow get them to tell it. Only this way" (E).

Finally, it is worth noting those benefits and improvements, which are associated with the expected organization-wide and systematic SCRM practices that are created and/or adapted in the company: 
- Whole organization coverage: “...guys have the information put together pretty good. We have a look at what is relevant from the legal perspective. The financial analyst could tell you more about this, he's doing the whole review" (D),

- Complex evaluation of risks: “...if this is for prevention, let's say it's some new client saying: now look at this from the legal perspective. So that mirror... I look at that mirror from the legal perspective, which is indicating trouble for us..." (D),

- Complex risk management: “...when buying, when taking out the products, check that everything is right with the documentation;... to avoid tax disputes and perhaps frauds... Because the more you demand, the more risks you are managing..." (G),

- Risk management becomes systematic: “... that information is somewhere, you take it - look we've been cautious, we have the circumstances of that deal, described by people, a phone number is there, who's the manager, his business card is added there as well" (B),

- Improved risk management processes: “...when the companies bankrupted, analyze them, add...variables. See what happened to them" $(\mathrm{G})$.

All in all, the results of the exploratory primary data research are illustrative and with the potential for conceptual and empirical outcomes. Empirically, the abovegiven summary is useful for the case company to develop and improve SCRM practices aiming at higher efficiency and wide application of AI tools. Conceptually, the results of the exploration are used to provide research data-based illustrative organization features, that could be employed as the research indicators or managerial checklist to assess the organization's progress towards the application of AI in SCRM. We are elaborating on this point in the next section of the paper.

\section{Discussion and Implications}

The in-depth analysis of collected quotes from empirical data let to provide a selection of illustrative features, that could be treated as indicators to be used to estimate the level of progress towards the application of AI in SCRM. It is noted here that the provided list should not be treated as an approved methodology. It is supposed to serve as an initial guide. The actual measurements or estimations could be done by using common categorical or nominal scales: yes/no counts, never, sometimes, often, always scale, and other measurement ways should be considered as appropriate. The number of points collected in two dimensions indicates the level of the progress towards the application of AI in SCRM.

Respectively, the nature of challenges in applying artificial intelligence for supply chain risk management would then be defined. The positioning of identified challenges, restrictions, and limitations in the above discussed theoretical framework (Figure 1) would suggest the directions for needed developments and improvements. 
Two main directions are expected for these developments and improvements: either they will have to be focussed on risk events' or risk indicators' data collection and systematization by the processes of storage, management, exchange, and application.

Table 4. Selection of illustrative organizational features that could be used to estimate the level of progress towards the application of AI in SCRM

\begin{tabular}{|c|c|c|}
\hline & $\begin{array}{l}\text { Risk events' data collection and } \\
\text { systematization }\end{array}$ & \begin{tabular}{|lll}
$\begin{array}{l}\text { Risk indicators } \\
\text { systematization }\end{array}$ & data collection and \\
\end{tabular} \\
\hline \multirow{2}{*}{$\begin{array}{l}\text { Data is not } \\
\text { collected, } \\
\text { not } \\
\text { systematized }\end{array}$} & $\begin{array}{l}\text { Sales contracts' details are entered } \\
\text { manually by sales managers }\end{array}$ & $\begin{array}{l}\text { The data about clients reach financial officers } \\
\text { as separate massages from range of different } \\
\text { data sources }\end{array}$ \\
\hline & $\begin{array}{l}\text { Occasions when clients' contracts } \\
\text { data do not match company's entries. }\end{array}$ & $\begin{array}{l}\text { Financial statements and other data about } \\
\text { clients is collected in scanned documents } \\
\text { format }\end{array}$ \\
\hline \multirow{5}{*}{$\begin{array}{l}\text { Individual } \\
\text { initiative- } \\
\text { based } \\
\text { practice }\end{array}$} & $\begin{array}{l}\text { Contracts related data is stored by } \\
\text { managers personally }\end{array}$ & $\begin{array}{l}\text { The data about clients is collected and stored } \\
\text { by the chief financial officers }\end{array}$ \\
\hline & $\begin{array}{l}\text { Late paying clients are suspended by } \\
\text { decisions of individual managers }\end{array}$ & $\begin{array}{l}\text { Commercial contracts related data remains } \\
\text { stored in managers e-mail correspondence }\end{array}$ \\
\hline & $\begin{array}{l}\text { Lists of debtors are updated by } \\
\text { managers }\end{array}$ & $\begin{array}{l}\text { Each functional department and managers have } \\
\text { their own lists indicators to estimate risk } \\
\text { potential }\end{array}$ \\
\hline & $\begin{array}{l}\text { Sorting of contracts to successful and } \\
\text { failed is performed manually by } \\
\text { managers }\end{array}$ & $\begin{array}{l}\text { Financial officers are responsible for periodical } \\
\text { clients' data updates from external data sources }\end{array}$ \\
\hline & \begin{tabular}{|l|}
$\begin{array}{l}\text { Managers are allowed to manage } \\
\text { their contracts during the holidays }\end{array}$ \\
\end{tabular} & $\begin{array}{l}\text { Law department officers are responsible for } \\
\text { periodical clients data updates from courts }\end{array}$ \\
\hline \multirow{8}{*}{$\begin{array}{l}\text { Organization } \\
\text { wide } \\
\text { systemic } \\
\text { practices }\end{array}$} & $\begin{array}{l}\text { There is the registry of the events } \\
\text { which cause losses or other troubles }\end{array}$ & $\begin{array}{l}\text { Operations of managers (e.g. number of sent e- } \\
\text { mails) are tracked for potential risk issues }\end{array}$ \\
\hline & $\begin{array}{l}\text { Events which cause losses or other } \\
\text { troubles are registered constantly, } \\
\text { chronologically }\end{array}$ & $\begin{array}{l}\text { Selected external indicators (e.g. average price) } \\
\text { are observed to track performance of products } \\
\text { categories }\end{array}$ \\
\hline & $\begin{array}{l}\text { Payments delays are checked and } \\
\text { clients are notified automatically }\end{array}$ & $\begin{array}{l}\text { Constant monitoring of clients data such as } \\
\text { expiration of export-import permissions, } \\
\text { registration code, VAT payer code, official } \\
\text { address and similar }\end{array}$ \\
\hline & $\begin{array}{l}\text { Critical payments delay time is set } \\
\text { and clients are suspended from } \\
\text { purchases }\end{array}$ & $\begin{array}{l}\text { Constant monitoring and updates of clients } \\
\text { credit insurance policies, credit limits, and } \\
\text { periods }\end{array}$ \\
\hline & Trackable payments history is stored & Trackable data on contracts details changes \\
\hline & $\begin{array}{l}\text { Trackable payments history covers } \\
\text { data on agreed payment delay } \\
\text { periods }\end{array}$ & $\begin{array}{l}\text { The exchange of contracts data among depart- } \\
\text { ments is automatized }\end{array}$ \\
\hline & $\begin{array}{l}\text { Transport orders are cross checked to } \\
\text { ensure that corresponding purchase } \\
\text { order actually exists }\end{array}$ & $\begin{array}{l}\text { All contracts documents digitalized uploaded } \\
\text { and processed for potential risks in supply and } \\
\text { sales contracts }\end{array}$ \\
\hline & $\begin{array}{l}\text { e-mails are filtered and only } \\
\text { approved senders are allowed to } \\
\text { reach managers }\end{array}$ & $\begin{array}{l}\text { Interactive profiles of clients, carriers, and } \\
\text { other supply chain partners are used to manage } \\
\text { data }\end{array}$ \\
\hline
\end{tabular}

Source: Own study.

Though this research did not consider different risk types or supply chain risk categories, empirical incidents, taken from real practice of certain case company, 
naturally, are related to the certain risk events or broader risk categories. The proposed list of illustrative organizational features includes SC risks related to buyers, clients (covering such events as delayed payments, underpayment, and other), contracts management-related risks (e.g. inappropriate quantity of shipped products, redundant transport orders), and internal managerial stuff related risks (loss-making contracts incompatible with the interests of an organization).

Regardless of certain risk events category, challenges in the application of AI for SCRM would occur due to limitations caused by lack of data systematization when SCRM management is dominated by practices based on individual experience and respective responsibility (as it is reported above representing results of empirical data exploration). The limitations of data on either risk events' (i.e. predicted) or risk indicators' (i.e. prediction) variables would cause challenges in applying AI for SCRM as long as both sides should be filled with appropriate data to employ tools of AI. Any implicitness in data processing covering collection, storing, data management, exchange still would cause challenges for the application of AI for SCRM as long as organization-wide infrastructure will be created and employed. Figure 2 represents this typology of challenges according to their scope and nature in applying AI for SCRM based on the risk management maturity concept.

Figure 2. Typology of challenges according to their scope and nature in applying AI for SCRM based on risk management maturity concept

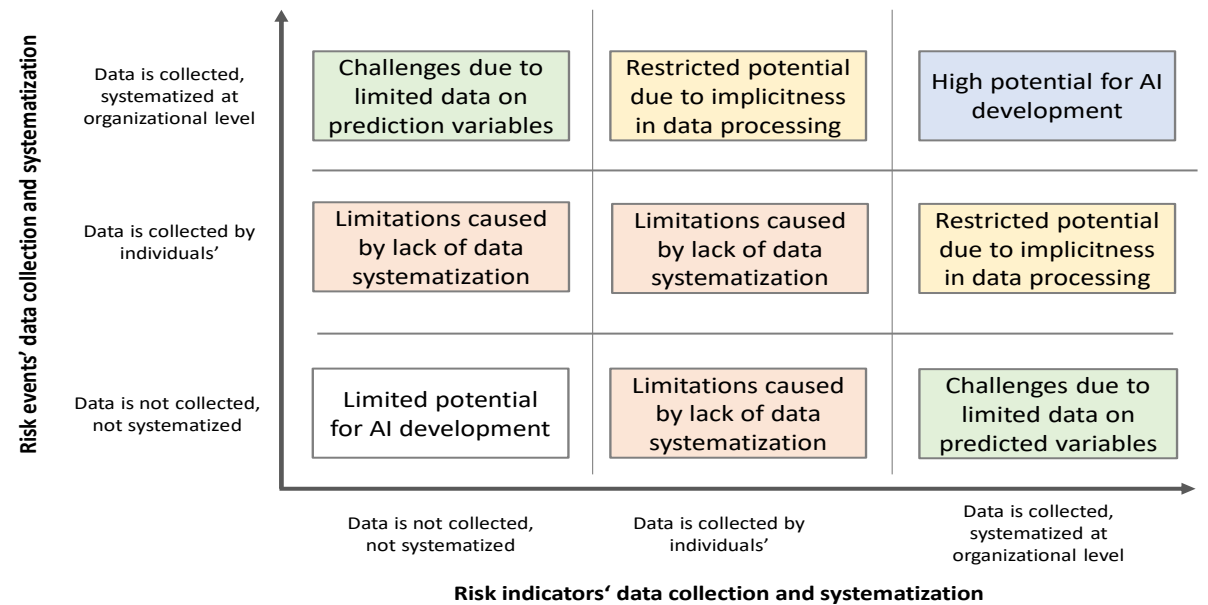

Source: Own study.

The proposed illustrative organizational features that could be used to estimate the level of progress towards the application of AI in SCRM (Table 4) are supposed to assist in indicating the current state and setting directions for required improvements. The selection of organizational features illustrating the variating nature of challenges is derived from a single case study and is expected to be expanded by other research in a different context in terms of sector of economic activity, geographical coverage, and other characteristics. 


\section{Conclusions}

To estimate the level of progress towards the application of AI in SCRM organizations should consider their management practices that concern data collection, storing, management, processing, exchange, and application for risk potential estimation. The data on risk events and associated indicators used to predict risk events are two data sources required by artificial intelligence tools. The main challenges in applying artificial intelligence for supply chain risk management arise due to limitations caused by a lack of needed data to calculated and then estimate the probability of considered risk event.

The case study empirical research was focussed on the supply chain risk management context. Case study empirical research lets us propose a list of illustrative practices that serve as an initial estimation guide to evaluate the level of progress towards the application of AI in SCRM.

Theoretical considerations and empirical research confirm that the scope of challenges in applying artificial intelligence for supply chain risk management extends along a range of managerial practices related to data collection, management, and application. These practices should be divided into those that are aimed at data about risk events and risk events indicators.

The forms, ways, and means of the above-mentioned data collection, storing, managing and application reveal the nature of challenges in applying artificial intelligence for supply chain risk management. The needed data could not be collected, stored, processed, and applied personally, in ways and forms that are not systematized, and approved by organization-wide systematized and interactive practices.

The settled nature of data collection, management, and application determines limitations, challenges and restrictions met in applying artificial intelligence for supply chain risk management. Limitations arise due to a lack of systematization in data collection, management, and application for risk estimation along both edges of the scope. Different challenges and restrictions arise when one of the directions is not developed appropriately. This framework helps to identify the paths for improvements.

The range of proposed illustrative features was determined by the business practice and nature of the selected case company activity. The coming research in other contexts and different types of organizations would be useful in extending the proposed list of illustrative practices. The extensive list of such practices would enable to take further steps in conceptualizing challenges in applying artificial intelligence for supply chain risk management and directions to overcome them. Then these illustrative practices will be clustered around certain risk categories and 
respective events, which would increase the practical applicability of the tool intended to estimate the level of the progress towards application of AI in SCRM.

\section{References:}

Abkowitz, M., Camp, J. 2017. Structuring an Enterprise Risk Assessment Protocol: Traditional Practice and New Methods. Risk Management and Insurance Review 20, 79-97.

Ain, N., Vaia, G., DeLone, W.H., Waheed, M. 2019. Two decades of research on business intelligence system adoption, utilization and success: A systematic literature review. Decision Support Systems, 125, 1-13.

Akerkar, R. 2019a. Employing AI in Business. In Artificial Intelligence for Business, R. Akerkar, ed. Cham: Springer International Publishing, 63-74.

Akerkar, R. 2019b. Introduction to Artificial Intelligence. In Artificial Intelligence for Business, R. Akerkar, ed. Cham: Springer International Publishing, 1-18.

Andriole, S.J. 2019. Artificial Intelligence, Machine Learning, and Augmented Analytics. IT Professional 21, 56-59.

Aqlan, F., Lam, S.S. 2015. A fuzzy-based integrated framework for supply chain risk assessment. International Journal of Production Economics 161, 54-63.

Bavarsad, B., Boshagh, M., Kayedian, A. 2014. A Study on Supply Chain Risk Factors and Their Impact on Organizational Performance.

Chen, H.L. 2018. Supply chain risk's impact on corporate financial performance. International Journal of Operations \& Production Management 38, 713-731.

Chen, T.K., Liao, H.H. 2018. Suppliers'/customers' production efficiency uncertainty and firm credit risk. Rev Quant Finan Acc, 50, 519-560.

Colicchia, C., Strozzi, F. 2012. Supply chain risk management: a new methodology for a systematic literature review. Supply Chain Management: An International Journal $17,403-418$.

Davenport, T.H. 2018. From analytics to artificial intelligence. Journal of Business Analytics 1, 73-80.

Dobrev, D. 2012. A Definition of Artificial Intelligence. ArXiv:1210.1568 [Cs].

Fan, Y., Stevenson, M. 2018. A review of supply chain risk management: definition, theory, and research agenda. International Journal of Physical Distribution \& Logistics Management 48, 205-230.

Farrell, M., Gallagher, R. 2015. The Valuation Implications of Enterprise Risk Management Maturity. Journal of Risk and Insurance, 82, 625-657.

Fraser, J.R.S., Simkins, B.J. 2016. The challenges of and solutions for implementing enterprise risk management. Business Horizons, 59, 689-698.

Gomm et al. 2000. Case Study Method. Key Issues, Key Texts, SAGE Publications.

Heckmann, I., Comes, T., Nickel, S. 2015. A critical review on supply chain risk Definition, measure and modeling. Omega, 52, 119-132.

ISACA. 2019. Effective Capability and Maturity Assessment Using COBIT 2019.

ISO. 2009. ISO Guide 73:2009.

Lindberg, D., Seifert, D. 2011. Enterprise Risk Management (ERM) Can Assist Insurers in Complying with the Dodd-Frank Act.

Noja, G.G. 2018. Flexicurity models and productivity interference in CEE countries: a new approach based on cluster and spatial analysis. Economic research-Ekonomska istraživanja 31(1), 1111-1136.

Oliva, F.L. 2016. A maturity model for enterprise risk management. International Journal of 
Production Economics, 173, 66-79.

Raisinghani, M. 2004. Business Intelligence in the Digital Economy: Opportunities, Limitations and Risks: Opportunities, Limitations and Risks. Idea Group Inc (IGI).

Siggelkow, N. 2007. Persuation With Case Study. Acad. Manage, 50, 20-24.

Soni, G., Kodali, R. 2013. A decision framework for assessment of risk associated with global supply chain. Journal of Modelling in Management, 8, 25-53.

Tecuci, G. 2012. Artificial intelligence. WIREs Computational Statistics, 4, 168-180.

Tse, Y.K., Chung, S.H., Pawar, K.S. 2018. Risk perception and decision making in the supply chain: theory and practice. Industrial Management \& Data Systems, 118, 1322-1326.

Tse, Y.K., Zhang, M., Tan, K.H., Pawar, K., Fernandes, K. 2019. Managing quality risk in supply chain to drive firm's performance: The roles of control mechanisms. Journal of Business Research, 97, 291-303.

Yin, R.K. 2009. Case study research: Design and methods (4th Ed.). Thousand Oaks, CA, Sage.

Žigienè, G., Rybakovas, E., Alzbutas, R. 2019. Artificial Intelligence Based Commercial Risk Management Framework for SMEs. Sustainability, 11, 4501. 